Document downloaded from:

http://hdl.handle.net/10251/81471

This paper must be cited as:

Theodet, M.; Quilfen, C.; Martínez, C.; Aymonier, C. (2016). Continuous supercritical synthesis of unsupported and high specific surface area catalyst precursors for deephydrodesulfurization. Journal of Supercritical Fluids. 117:252-259. doi:10.1016/j.supflu.2016.07.002.

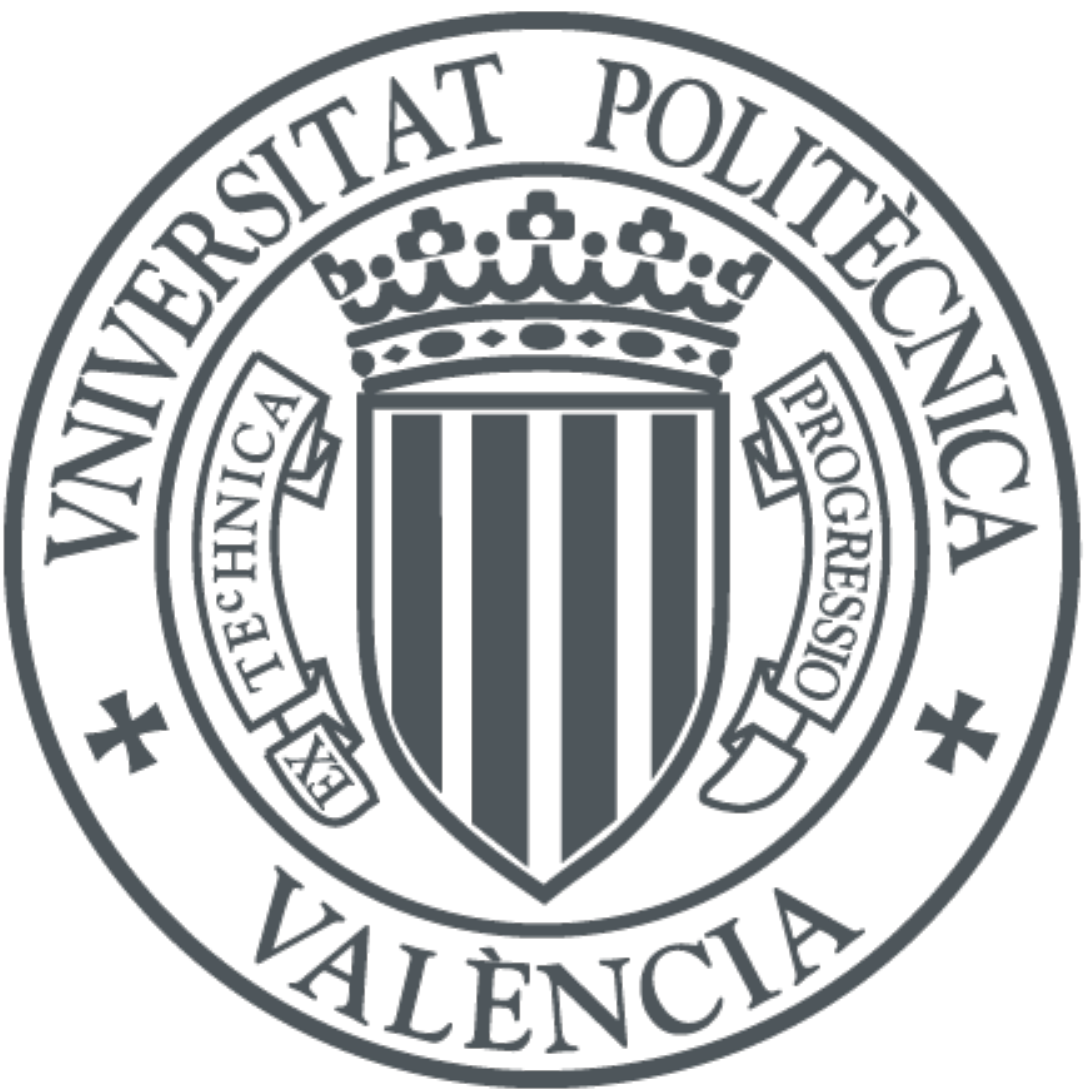

The final publication is available at

http://dx.doi.org/10.1016/j.supflu.2016.07.002

Copyright Elsevier

Additional Information 


\title{
Continuous supercritical synthesis of unsupported and high specific surface area catalyst precursors for deep- hydrodesulfurization
}

\author{
M. Théodet ${ }^{a, b, c}$, C. Quilfen ${ }^{a, b}$, C. Martínez ${ }^{c, *}$ and C. Aymonier ${ }^{a, b, *}$
}

\begin{abstract}
Unsupported and high specific surface area (SBET) catalyst precursors for deephydrodesulfurization (deep-HDS) are obtained using an environmental friendly, continuous and fast synthesis process in supercritical water/alcohol mixtures. This approach offers an access to high production rate and upscaling. Two mixed oxides were synthesized: $\mathrm{NiMoO}_{4}$, which is the preferred material when deep-HDS is investigating, and $\mathrm{CoMoO}_{4}$ preferred for simple HDS. The role of the water/alcohol mixture on the resulting specific surface area has been studied and allows a controlled adjustment of the resulting specific surface area. The obtained $\mathrm{NiMoO}_{4}$ material consists of the highly active hydrate $\mathrm{NiMoO}_{4} \cdot 0.75 \mathrm{H}_{2} \mathrm{O}$ phase with a controlled composition and specific surface area up to $200 \mathrm{~m}^{2} \cdot \mathrm{g}^{-1}$. Resulting materials have shown great performances when tested in deep-HDS catalytic tests.
\end{abstract}

\section{Introduction}

Due to increasingly stringent environmental regulations in sulfur limits for distillates fuels, production of ultra-low sulfur content fuels is required to reach the limits of $10 \mathrm{ppm}$ in the European Union ${ }^{1}$ and Japan ${ }^{2}$ and 15 ppm in North America ${ }^{3,4}$. Moreover, remaining available crude oils resources contain a greater amount of undesirable heteroatoms that will have to be removed. Removals of $99.99 \%$ of sulfur from typical crude oil and the corresponding processes have been termed as deep-HDS. The main issue of deep-HDS is the elimination of refractory sulfur compounds such as 4,6-dimethyldibenzothiophene (4,6DMDBT). In order to achieve this issue without expensive costs in process modifications, the development of more efficient deep-HDS catalysts is required.

Typically, a HDS catalyst contains a metal from the group VIB (chromium, molybdenum or tungsten) promoted with a metal from the group VII (cobalt or nickel) and supported, classically, on alumina ${ }^{5-7}$. These conventional catalysts are generally obtained by impregnation of $\gamma-\mathrm{Al}_{2} \mathrm{O}_{3}$ with aqueous solutions of $\left(\mathrm{NH}_{4}\right)_{6} \mathrm{Mo}_{7} \mathrm{O}_{24} .4 \mathrm{H}_{2} \mathrm{O}$ and $\mathrm{Co}\left(\mathrm{NO}_{3}\right)_{2} .6 \mathrm{H}_{2} \mathrm{O}$ or $\mathrm{Ni}\left(\mathrm{NO}_{3}\right)_{2} .6 \mathrm{H}_{2} \mathrm{O}$ followed by drying, calcination and activation under $\mathrm{H}_{2} / \mathrm{H}_{2} \mathrm{~S}{ }^{8}$ in order to obtain $\mathrm{MoS}_{2}$ layers well dispersed on the $\gamma-\mathrm{Al}_{2} \mathrm{O}_{3}$ support and edges-decorated with $\mathrm{Co}$ or $\mathrm{Ni} 9$. However, current HDS catalysts revealed to be insufficient and strong optimizations have been investigated over the past decades, such as improvement of the support and/or of the active phase $^{10}$.

On the other hand, some unsupported materials have been described with higher activity and/or selectivity than traditional supported catalysts, leading to a growing interest in unsupported HDS nano-catalysts ${ }^{11-20}$. This category of catalysts can easily be obtained by thermal decomposition ${ }^{21,22}$, metal amines metallates ${ }^{16}$, hydrothermal ${ }^{23}$, citrate ${ }^{24}$, freeze-drying ${ }^{25}$ and impregnation 26 for the most classical methods. However, their main weakness compared to supported catalysts is their low specific surface area ( $\mathrm{S}_{\mathrm{BET}}$ ), down to 10 to $80 \mathrm{~m}^{2} \cdot \mathrm{g}^{-1}$ for most of the unsupported catalysts 16,21,26-29. However recent works have reported maximum values for $S_{\text {BET }}$ around 200 to $300 \mathrm{~m}^{2} \cdot \mathrm{g}^{-1}$ 30,31, similar than those presented by alumina supported catalysts (200 to 300 $\left.\mathrm{m}^{2} \cdot \mathrm{g}^{-1}\right)^{32}$.

Increasing $\mathrm{S}_{\mathrm{BET}}$ appears to be a very interesting challenge in the development of this new generation of catalysts but most of the time, high $\mathrm{S}_{\text {BET }}$ unsupported catalysts synthesis generate toxic compounds and therefore are difficult to implement as industrial scale ${ }^{31}$. In order to do so, supercritical fluids technologies are known to be efficient to prepare highly dispersed nanostructures ${ }^{33}$ and nanopowders with high $\mathrm{S}_{\mathrm{BET}^{34,35}}$ without generation of toxic compounds. In this work we propose the use of green solvents (water/alcohols), inexpensive (ten times cheaper than the ones use in conventional methods for high $\mathrm{S}_{\text {BET }}$ materials ${ }^{31}$ ) and friendly precursors. Moreover, our approach allows the synthesis of crystalline materials with controlled and adjustable composition ${ }^{36-39}$ but also with a tuneable specific surface area ${ }^{34}$ by playing with the carbon length of the alcohol used. These materials are produced in a fast, sustainable and continuous process which is a major asset for upscaling ${ }^{40}$. All these advantages are obviously linked to the good activities of our materials in deep-HDS. Our catalyst precursors have shown a similar activity in removing the most refractory compound (4,6-DMDBT) to those of a reference catalyst but to a lower reaction temperature of $40^{\circ} \mathrm{C}$. As far as we know, the use of this 
method to synthesize $\mathrm{Ni}(\mathrm{Co}) \mathrm{MoO}_{4}$ has not been so far reported in the literature.

\section{Experimental}

Materials and methods

Bis(acetylacetonato)dioxomolybdenum(VI)

$\left(\mathrm{MoO}_{2}\left(\mathrm{CH}_{3} \mathrm{COCHCOCH}_{3}\right)_{2}\right.$, Alfa Aesar, 99\%), nickel(II) acetate tetrahydrate $\left(\mathrm{Ni}\left(\mathrm{CH}_{3} \mathrm{COO}\right)_{2} .4 \mathrm{H}_{2} \mathrm{O}\right.$, Alfa Aesar, $\left.99 \%\right)$ and cobalt(II) acetate tetrahydrate $\left(\mathrm{Co}\left(\mathrm{CH}_{3} \mathrm{COO}\right)_{2} .4 \mathrm{H}_{2} \mathrm{O}\right.$, Alfa Aesar, $98 \%$ ) were used without further purification.

Synthesis procedures

The starting $\mathrm{Ni}(\mathrm{Co})$ - and Mo-containing solutions were prepared as follows: Mo salt was dissolved in a water/alcohol mixture of molar ratio $1: 1$ and $\mathrm{Ni}(\mathrm{Co})$ precursor was previously dissolved in distilled water before adding the same quantity of alcohol in order to prevent the precipitation due to alcohol aversion of the acetate. The alcohols used in this study were methanol, ethanol and isopropanol. Molybdenum concentration was fixed at $[\mathrm{Mo}]=7 \cdot 2 \cdot 10^{-3} \mathrm{~mol} \cdot \mathrm{L}^{-1}$ and $\mathrm{Ni}$ concentration was adjusted to vary the metal molar ratios $(36-50-57-60-66$ at $\%$ ). For cobalt, the concentration used was equal to the one of Mo. Those solutions of precursors were then injected in a continuous reactor, where they reached supercritical conditions, typically for a residence time of $55 \mathrm{~s}^{37,38}$. A chemical reaction takes place leading to the nucleation and growth of the NiMo or CoMo nanoparticles. These last ones followed their way to a filter deepened in an ice bath to quench their growth. The obtained powder was washed with distilled water, recovered by vacuum filtration and dried at room temperature before a thermal treatment at $400^{\circ} \mathrm{C}$ for 3 hours.

\section{Characterization techniques}

Metal ratios were determined by Inductively Coupled Plasma/Optical Emission Spectrometry (ICP-OES) using a Varian 720-ES equipment. Carbon pollutions were detected using CHNS-O analysis, accomplished by combustion analysis according to the Pregl-Dumas procedure. The equipment used was a Flash EH 1112 from Thermo Fisher.

X-Ray powder diffraction (XRD) patterns were obtained from a Philips PW1820 and a PANalytical X'Pert X-Ray diffractometers in Bragg-Brentano geometry equipped with $\mathrm{Cu}$ $\mathrm{K} \alpha 1$ source and an $\mathrm{X}^{\prime}$ Celerator detector. Diffraction patterns were collected with a $2 \theta$ step of $0.02^{\circ}$ and a $0.0358^{\circ} \cdot \mathrm{s}^{-1}$ scan speed routine mode; for more advanced investigations a $0.008^{\circ}$ step and a $0.0053^{\circ} . \mathrm{s}^{-1}$ scan speed were used on a PANalytical $\mathrm{X}^{\prime}$ Pert pro MOO equipped with primary Ge (111) monochromator $\mathrm{Cu} \mathrm{K} \alpha 1$ source. The cell fitting, and thus the cell volume, were obtained by profile fitting of the pattern with the FULLPROF program. The fits were performed using a pseudoVoigt peal-shape function. In the final runs, the usual profile parameters (scale factors, background coefficients, zero point, half-widths, pseudo-Voigt and asymmetry parameters for the peak shape) were refined.

The morphology of the powders was observed using a scanning electron microscope (JEOL 6700F) operating at an accelerating voltage of $30 \mathrm{kV}$. The size of the nanoparticles was evaluated using a high-resolution transmission electron microscope (JEOL JEM-2200FS) enable to switch to a scanning mode to make chemical X-Ray mapping of nanoparticles.

Physisorption measurements were performed using an Autosorb-1 instrument from Quantachrome. The BET specific areas were determined by $\mathrm{N}_{2}$ adsorption at $77 \mathrm{~K}$ assuming a cross-sectional area of $0.162 \mathrm{~nm}^{2}$ for the nitrogen molecule. Prior to adsorption measurements, the samples were outgassed in a vacuum at room temperature for 2 hours.

\section{Catalytic tests}

The model feedstock used was composed of $60 \mathrm{wt} \%$ of paraffins, $30 \mathrm{wt} \%$ of olefins and $10 \mathrm{wt} \%$ of aromatic hydrocarbons, in order to deal with a possible "matrix effect". The detailed composition can be found in Table S3 enclosed in S.I. The total sulfur content was 500 wppm with 100 wppm as 4,6-DMDBT, the most refractory compound. No nitrogen compounds were added to the feedstock in order to avoid the competition with HDN.

The activity tests were conducted in a fixed bed tubular reactor. The reactor was charged with $160 \mu \mathrm{L}$ of catalyst (pelletized at a diameter comprised between $0.250 \mu \mathrm{m}$ and 0.425 $\mu \mathrm{m}$ ) and diluted in $\mathrm{SiC}$ (diluent/catalyst volume ratio of 12). The activation of the catalyst was done in situ using a mixture of $\mathrm{H}_{2} \mathrm{~S} / \mathrm{H}_{2}$ with 10 vol\% $\mathrm{H}_{2} \mathrm{~S}$ at atmospheric pressure and a temperature of $400^{\circ} \mathrm{C}$ for $3 \mathrm{~h}$. The reaction conditions were the following: total pressure of $3.5 \mathrm{MPa}$, temperature of reaction between 320 and $400^{\circ} \mathrm{C}$, Liquid Hourly Space Velocity (LHSV) of $39 \mathrm{~h}^{-1}$ and a ratio $\mathrm{H}_{2}$ /feed of 5 . For each test, liquid samples were accumulated, weighted and analyzed at intervals of about $40 \mathrm{~min}$. For all catalysts, a constant composition of the reactor outlet stream was observed after reaction periods of 3 to $4 \mathrm{~h}$. Results reported in this work correspond to the steady-state period of operation. The composition of feed and products was analyzed by gas chromatography in a Varian 3800 equipped with a 30 m column (VF $5 \mathrm{~ms}$ CP8944) with an inner diameter of 0.25 $\mathrm{mm}$ and a bonded stationary phase made of a $0.25 \mu \mathrm{m}$ thick film of (5\% phenyl, $95 \%$ dimethyl) polysiloxane, and two detectors, a Flame Ionization Detector and a sulfur specific Pulsed Flame Photometric Detector.

\section{Results and discussion}

NiMo based catalyst precursors for deep HDS

$\mathrm{NiMoO}_{4}$ may exist in several polymorphs at atmospheric pressure: the low temperature stable $\alpha$-phase ${ }^{41}$, the high temperature stable $\beta$-phase ${ }^{42}$ and the hydrate $\mathrm{NiMoO}_{4} \cdot \mathrm{nH}_{2} \mathrm{O}$ $(n=0,75,1)$ phase ${ }^{43-46}$. According to the literature, the pure $\beta$ - 
phase is generated by heating the $\alpha-\mathrm{NiMoO}_{4}$ at temperatures above $690^{\circ} \mathrm{C}$ and is stable only if kept over $180^{\circ} \mathrm{C} 28,47$.

Both phases ( $\alpha$ and $\beta$ ) are monoclinic with space group $\mathrm{C} 2 / \mathrm{m}$ 48. The structural building units of $\alpha-\mathrm{NiMoO}_{4}$ (isotypic with $\alpha$ $\mathrm{CoMoO}_{4}{ }^{41}$ ) are $\mathrm{NiO}_{6}$ and $\mathrm{MoO}_{6}$ distorted octahedra, which share edges and form chains parallel to the "c" direction. Each chain is surrounded by four other chains and linked to them by corner sharing of oxygen atoms. Between the filled chains there are chains of unfilled octahedra. It also presents alternative layers of NiMo6 and $\mathrm{MoO}_{6}$ parallel to the "b" direction. The structure of $\beta-\mathrm{NiMoO}_{4}$ is isotypic with $\alpha-\mathrm{MnMoO}_{4}$ (ICSD \#78328). By analogy, it consists of molybdate distorted tetrahedra, which share corners with four different nickelate octahedra. The general description is similar to the $\alpha$-phase with chains joined by corner sharing of oxygen atoms and with chains of unfilled octahedral between them. The difference between the two phases is a contraction in the "c" axis and an expansion in the "a" and " $b$ " axes of the cell in the $\beta$-form compared to the $\alpha$-form. The formal oxidation state of $\mathrm{Ni}$ is $+\mathrm{II}$, whereas the one of Mo is + VI as in $\mathrm{MoO}_{3}{ }^{44}$.

Recent studies give a description of the hydrated phase $\mathrm{NiMoO}_{4} \cdot \mathrm{nH}_{2} \mathrm{O}$ with $\mathrm{n}=1$ or $0.75^{46}$. Measurements of differential thermal analysis (DTA) suggest that in these systems the metal cations have a coordination similar to that observed in $\beta$ $\mathrm{NiMoO}_{4}$. The $\mathrm{NiMoO}_{4} .0 .75 \mathrm{H}_{2} \mathrm{O}$ structure has been described as a triclinic system (space group $P$-1) with tetrameric $z$-shaped unit of $\mathrm{Ni}$ octahedra, two $\mathrm{NiO}_{6}$ and two $\mathrm{NiO}_{5}\left(\mathrm{OH}_{2}\right)$, that share edges. These units are interconnected by $\mathrm{MoO}_{4}$ tetrahedra to form a network structure with open channels ${ }^{46}$. NiMoO $4 . \mathrm{H}_{2} \mathrm{O}$ might present a similar structure with lattice and coordination water. The HDS activity of these systems increased in the following order: $\alpha<B<$ hydrate ${ }^{27,28}$.

The TGA-MS of the powders obtained directly after synthesis in supercritical water/alcohol system displays three main mass losses for a total mass loss of $8 \mathrm{wt} \%$ (see Figure S1 enclosed in S.I.). A first loss of $2.8 \mathrm{wt} \%$ between room temperature and $243{ }^{\circ} \mathrm{C}$ can be attributed to adsorbed water as shown in the mass spectrometry results (line of mass 18). The second mass loss of $4.20 \mathrm{wt} \%$ occurring from $243{ }^{\circ} \mathrm{C}$ to $468{ }^{\circ} \mathrm{C}$ can be attributed this time to the departure of structural water and some carbon according to the line shape of masses 18 and 44 (CHNS-O analyses give a mean of $0.4 \mathrm{wt} \%$ carbon in the powders) as for the third mass loss of $0.5 \mathrm{wt} \%$ between $468^{\circ} \mathrm{C}$ and $538^{\circ} \mathrm{C}$. The last mass loss which occurred between $538^{\circ} \mathrm{C}$ and $800^{\circ} \mathrm{C}$ seems to be exclusively due to the carbon departure. Those water losses are in good agreement with results obtained by Rodriguez et al. ${ }^{43}$ and Eda et al. ${ }^{46}$ on their study of $\mathrm{NiMoO}_{4} \cdot \mathrm{nH}_{2} \mathrm{O}$ ( $\mathrm{n}=0.75$ or 1$)$. Upon heating $\mathrm{NiMoO}_{4} \cdot \mathrm{nH}_{2} \mathrm{O}$ to high temperatures in TGA-MS experiments, they also observed that water desorbs in three peaks. The first at $100-200{ }^{\circ} \mathrm{C}$ is associated with water molecules reversibly bounded to the hydrate. The second from 200 to $400{ }^{\circ} \mathrm{C}$ corresponds to desorption of water molecules that form part of the hydrate crystal structure, and they also assessed that at the onset of this peak, the formation of $\beta-\mathrm{NiMoO}_{4}$ starts. They pointed out an additional small desorption peak between $490{ }^{\circ} \mathrm{C}$ and $520^{\circ} \mathrm{C}$, also attributed to water. Eda considers that the ideal hydrate is $\mathrm{NiMoO}_{4} .0 .75 \mathrm{H}_{2} \mathrm{O}$, and based on the mass loss obtained with our TGA, we may approximate the same value for our material.

The XRD patterns shown in Figure 1 are representative of the products resulting from the synthesis in supercritical water/alcohol system ((a) isopropanol, (b) ethanol). Most of the peaks can be assigned to the above mentioned hydrate nickel molybdate $\mathrm{NiMoO}_{4} \cdot \mathrm{xH}_{2} \mathrm{O}$ (JCPDS $\mathrm{N}^{\circ}$ 13-0128) (no defined value for $\mathrm{x}$, structure represented in Figure 1); this is consistent with the assumption made previously. The presence of $\mathrm{MoO}_{3} . \mathrm{H}_{2} \mathrm{O}$ (JCPDS $\mathrm{N}^{\circ}$ 01-0125) and $\mathrm{MoO}_{2}$ (JCPDS $\mathrm{N}^{\circ}$ 32$0671)$ is also detected. This is due to an excess of Mo in those specific samples. More surprisingly, B-NiMoO 4 (JCPDS $\mathrm{N}^{\circ} 45-$ 0142) is also detected despite the fact that it is not stable at room temperature. During thermal treatment $\left(400{ }^{\circ} \mathrm{C}, 3 \mathrm{~h}\right.$, air atmosphere), the most remarkable features observed on XRD patterns acquired in temperature are the systematic transition of the hydrate $\mathrm{NiMoO}_{4} \cdot 0.75 \mathrm{H}_{2} \mathrm{O}$ into $\beta-\mathrm{NiMoO}_{4}$ at $400{ }^{\circ} \mathrm{C}$ while heating and the systematic transition into $\alpha-\mathrm{NiMoO}_{4}\left(\mathrm{JCPDS}^{\circ}\right.$ 86-0361) at $200{ }^{\circ} \mathrm{C}$ when cooling down. The nature of these two phases has been assessed by Rietveld refinement with fairly good refinement parameters ( $B$ : Bragg $\mathrm{R}$-factor $=4.96, \chi^{2}=2.38, \mathrm{cR}_{\mathrm{wp}}$ $=14.3$; $\mathrm{\alpha}$ : Bragg R-factor $=7.35, \chi^{2}=4.11, \mathrm{cR}_{\mathrm{wp}}=14.2$, see Table S1 and Table S2 enclosed in S.I.).

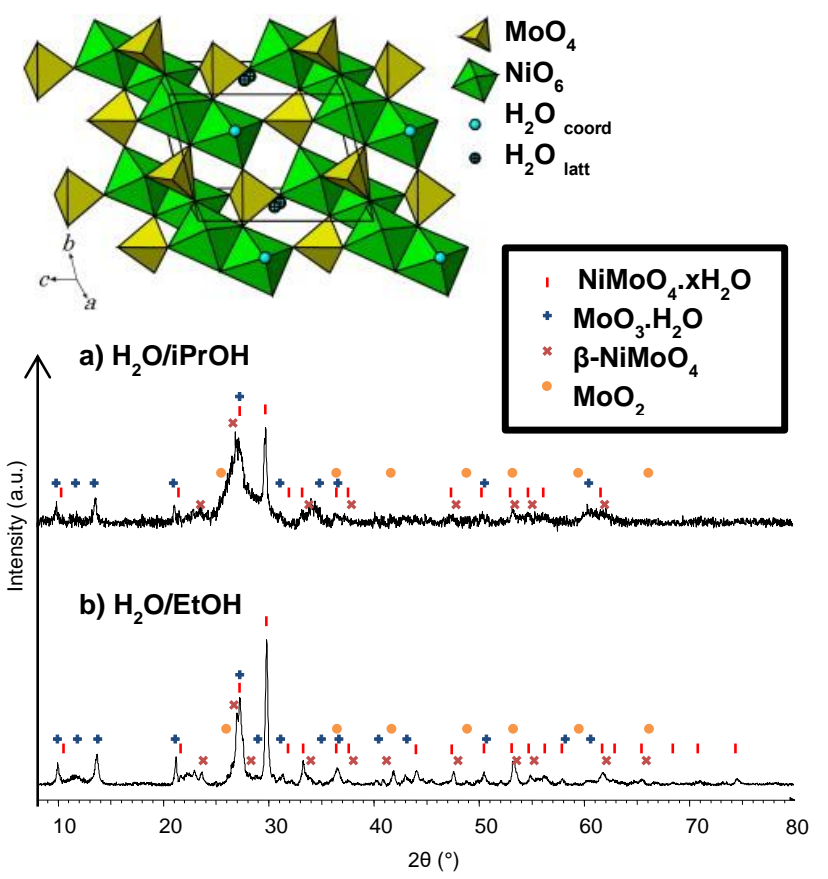

Figure 1: XRD patterns of a stoichiometric "NiMo" based powder synthesized in a) $\mathrm{scH}_{2} \mathrm{O} / \mathrm{iPrOH}$ and b) $\mathrm{scH}_{2} \mathrm{O} / \mathrm{EtOH}$. Above is the structure of $\mathrm{NiMoO}_{4} \cdot 0.75 \mathrm{H}_{2} \mathrm{O}$ (from Eda et al. ${ }^{37}$ )

The SEM micrographs of the as-obtained powders and calcined powders $\left(400{ }^{\circ} \mathrm{C}, 3 \mathrm{~h}\right)$ are shown in Figure 2.a) (synthesis carried out in ethanol). The as-obtained powders mainly consist of rod-like $\mathrm{NiMoO}_{4} \cdot 0.75 \mathrm{H}_{2} \mathrm{O}$ particles of dispersed sizes. After calcination the rods have collapsed and somehow sintered. 
The most interesting result obtained concerns the evolution of the specific surface area as a function of the alcohol nature as illustrated in Figure 2.b. The nature of the alcohol used plays a major role on the specific surface area, that increases from a value of $79 \mathrm{~m}^{2} \cdot \mathrm{g}^{-1}$ using methanol as solvent up to $179 \mathrm{~m}^{2} \cdot \mathrm{g}^{-1}$ using isopropanol as solvent. This result is fully consistent with a previous study on the formation of $\mathrm{CeO}_{2}$ nanocrystals in supercritical alcohols ${ }^{34}$. $\mathrm{CeO}_{2}$ nanopowders exhibit specific surface areas of 60,106 and $140 \mathrm{~m}^{2} \cdot \mathrm{g}^{-1}$ when prepared in pure methanol, ethanol and isopropanol, respectively. The same trend is observed for NiMo synthesis in the $\mathrm{H}_{2} \mathrm{O} / \mathrm{ROH}$ systems. This means that the alcohol is playing the role of solvent with water but also of functionalization agent as demonstrated for $\mathrm{CeO}_{2}{ }^{49}$ with a direct impact on the catalyst precursor thermal stability ${ }^{34}$.

a)
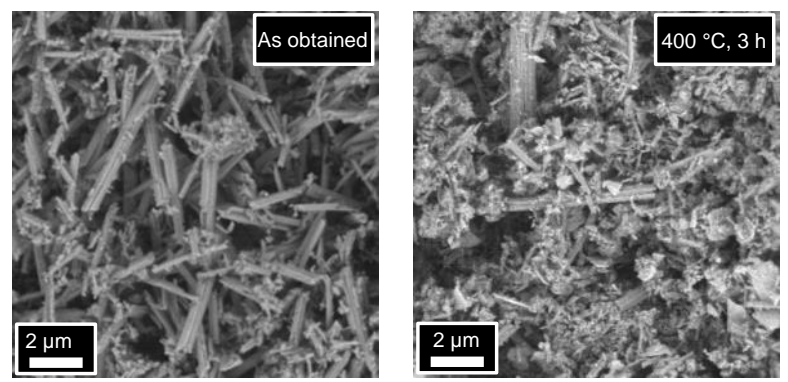

b)

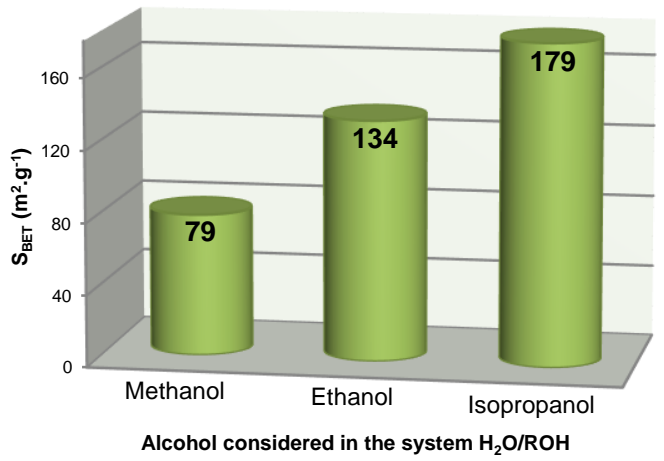

Figure 2: a) SEM micrographs of as obtained powder synthesized in $\mathrm{H}_{2} \mathrm{O} / \mathrm{EtOH}$ mixture on the left and the same powder treated for $3 \mathrm{~h}$ at $400^{\circ} \mathrm{C}$ on the right and b) Evolution of the catalyst precursor $\mathrm{S}_{\mathrm{BET}}$ as a function of the alcohol nature used in the supercritical solvent before thermal treatment.

XRD patterns of calcined powders $\left(3 \mathrm{~h}\right.$ at $\left.400{ }^{\circ} \mathrm{C}\right)$ with a different cations ratio are displayed in Figure 3. Two trends arise: for $\mathrm{Ni} / \mathrm{Mo}<1$, we obtain the $\mathrm{a}-\mathrm{NiMoO}_{4}$ phase together with $\mathrm{MoO}_{3} .2 \mathrm{H}_{2} \mathrm{O}$ phase (XRD pattern of the powder with 64 at $\%$ of $\mathrm{Mo}$ ) and for $\mathrm{Ni} / \mathrm{Mo}>1$, we obtain both $\alpha$ - and $\beta$-phases of $\mathrm{NiMoO}_{4}$ together with $\mathrm{NiO}$.

The STEM-EDX chemical mapping associated with these two compositions illustrates this fact showing the presence of particles containing only Mo for a) and particularly rich in Ni for b). These results are in agreement with studies carried out by $\mathrm{Di}$ Renzo et al. ${ }^{50,51}$ concerning the stabilization of $\beta-\mathrm{NiMoO}_{4}$ at room temperature with an excess of nickel. According to their work, only the $\alpha$-phase can be considered as a stoichiometric
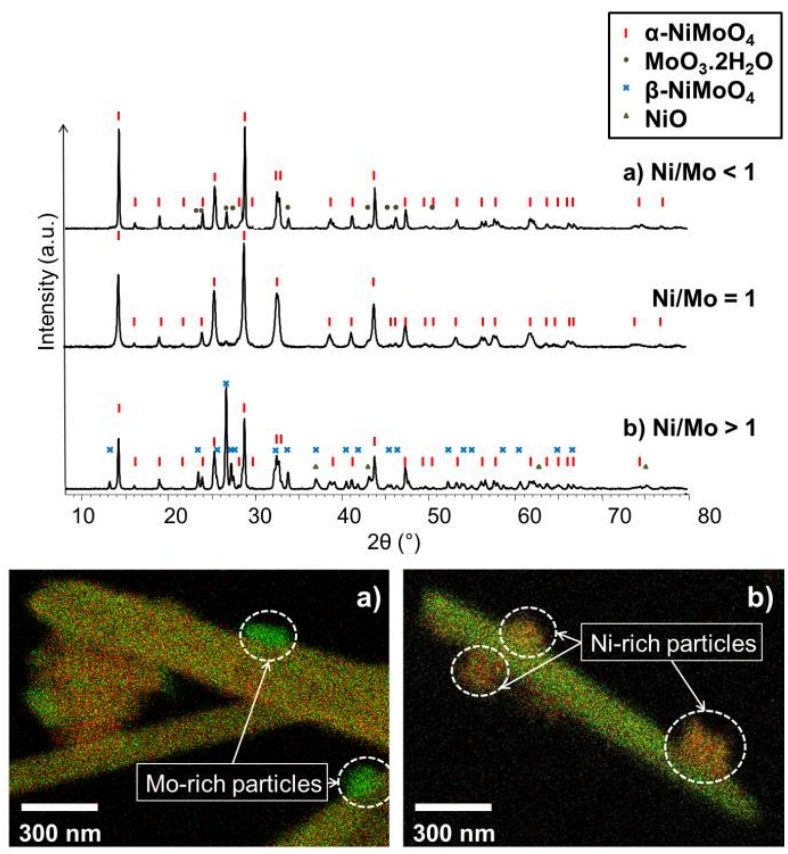

compound whereas the $\beta$-phases can form solid solutions with $\mathrm{Ni}$ by insertion in localized vacant sites in the network of $B$ $\mathrm{NiMoO}_{4}$, thus stabilizing its structure. This effect is not observed with Mo assumingly due to an obvious matter of steric hindrance. Figure 3: XRD patterns and their associated SEM-EDX chemical mappings of "NiMo" based powder synthesized in supercritical $\mathrm{H}_{2} \mathrm{O} / \mathrm{iPrOH}$ mixture with a) an excess of Mo and b) an excess of Ni. Powders are calcined $3 \mathrm{~h}$ at $400^{\circ} \mathrm{C}$

For most of the synthesized samples, the hydrate nickel molybdate phase was obtained with another phase depending of the stoichiometric ratio of each element.

CoMo catalyst precursors for deep HDS

Since our main objective concerns deep-HDS, $\mathrm{CoMoO}_{4}$ was not the privileged material since it is less efficient than $\mathrm{NiMoO}_{4}$. However, it was interesting to study the application of our fast (55s) and continuous synthesis method on $\mathrm{CoMoO}_{4} \cdot \mathrm{CoMoO}_{4}$ can adopt two different polymorphic forms, $\alpha$ and $\beta^{52}$. The $\beta$ $\mathrm{CoMoO}_{4}$ is the high temperature stable phase. Like in $\mathrm{NiMoO}_{4}$, the structure of the $\beta$ form is monoclinic (space group $C 2 / m$ ) with 6 and 4 as coordination numbers, respectively for $\operatorname{Co}(\mathrm{II})$ and $\mathrm{Mo}(\mathrm{VI})$. The structure of the $\alpha-\mathrm{CoMoO}_{4}$ is also monoclinic with the same space group. It is more compact and differs from $\beta$ $\mathrm{CoMoO}_{4}$ in the coordination of $\mathrm{Mo}(\mathrm{VI})$ which is 6 in this case. The difference between the two phases again lies is a contraction in the "c" axis and an expansion in the "a" and " $b$ " axes of the cell.

The XRD pattern acquired directly after reaction fits with a mixture of the two different structures of $\mathrm{CoMoO}_{4}$ (Figure 4.a). The $\beta$-isomorph is clearly the majority phase. Nothing surprising since it has already been proved that, unlike $\mathrm{B}-\mathrm{NiMoO}_{4}$, which is unstable below $180{ }^{\circ} \mathrm{C}, \beta-\mathrm{CoMoO}_{4}$ can be easily stabilized at 
room temperature ${ }^{52}$. As the XRD patterns also shown (Figure 4.b), the $\alpha$-phase almost disappears after thermal treatment at 400 ${ }^{\circ} \mathrm{C}$ for $3 \mathrm{~h}$.

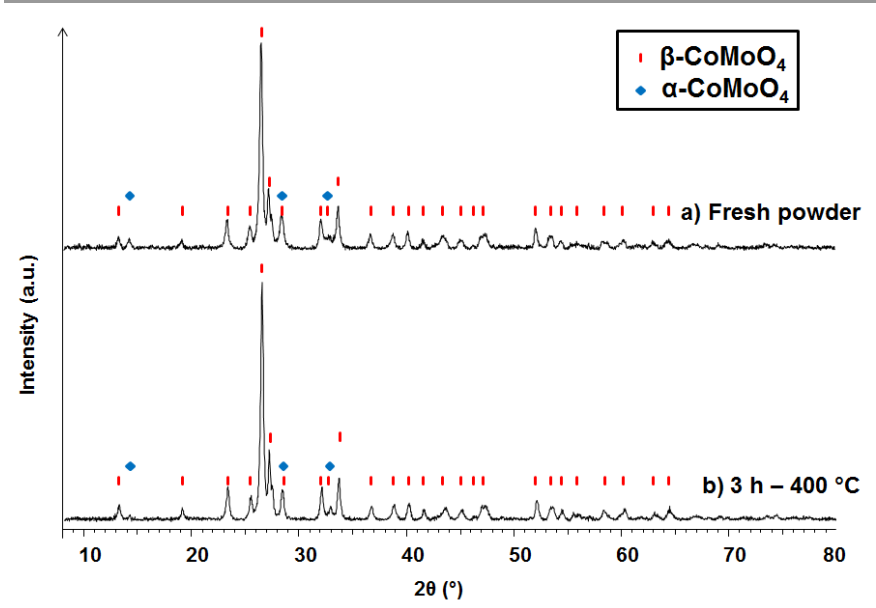

Figure 4: XRD patterns of stoichiometric "CoMo" based powders synthesized in $\mathrm{scH}_{2} \mathrm{O} / \mathrm{iPrOH}$ mixture with a) the obtained powder and b) after calcination for $3 \mathrm{~h}$ at $400^{\circ} \mathrm{C}$.

Catalytic tests

The catalytic behaviour of these materials was evaluated by comparison with a commercial supported catalyst, $\mathrm{NM}$, used as reference $\left(200 \mathrm{~m}^{2} \cdot \mathrm{g}^{-1}, 4 \mathrm{wt} \% \mathrm{NiO}, 14 \mathrm{wt} \% \mathrm{MoO}_{3} / \gamma-\mathrm{Al}_{2} \mathrm{O}_{3}\right)$.

In order to study the influence of the composition in our unsupported catalysts, three different compositions with a ratio $\mathrm{Ni} / \mathrm{Mo}>1$ were tested and compared to the reference supported catalyst. First, the materials with a Ni atomic fraction of 54 at\% (MT044) and of 62 at\% (MT072) were tested at a LHSV of $39 \mathrm{~h}^{-1}$ and results are presented in Figure 5.a. In a second series, the materials with a $\mathrm{Ni}$ atomic fraction of 69 at\% (MT043) and of 62 at\% (MT072) were tested at a LHSV of $150 \mathrm{~h}^{-1}$ and results are presented in Figure 5.b. 4,6-DMDBT conversion is presented in absolute values (top) and normalized considering the total surface area (bottom) in order to focus on the effect of the composition and minimizing the contribution of the specific surface area.

The results show that our bulk materials are significantly more active than the commercial reference when we directly compare the 4,6-DMDBT conversion obtained with catalysts MT044 and MT072 at our lowest operation temperature of $320^{\circ} \mathrm{C}$ (see Figure 5-a, top). The DMDBT conversion values obtained with these unsupported catalysts at $320^{\circ} \mathrm{C}$ are comparable to the conversion given by the $\mathrm{NiMo} / \mathrm{Al}_{2} \mathrm{O}_{3}(\mathrm{NM})$ at $360^{\circ} \mathrm{C}$. Thus, for similar conversion and similar amount of catalyst, the unsupported nanostructured catalysts can operate at lower temperature than $\mathrm{NM}$ and therefore, for similar conversion under similar operating conditions, a lower mass of our catalyst would be required to achieve the same conversion levels of the commercial reference. The lower activity of NM at lower temperature becomes even more evident when the results are given as surface area activities, normalized according to the BET surface area of the catalysts (see Figure 5 -a, bottom). In previous publications ${ }^{13}$, the activity of unsupported HDS catalysts was only comparable to that of commercial $\mathrm{Al}_{2} \mathrm{O}_{3}$ supported catalysts, and the latter was surpassed only when normalized to the catalyst surface area. Eijsbouts et al. ${ }^{12}$ have shown that addition of unsupported transition metal sulfide catalysts (Nebula ${ }^{\circledR}$ belonging to the NEBULA catalyst family developed by Albemarle Catalysts and ExxonMobil) to a conventional HDS catalyst allows decreasing their ULSD operation temperature in $15^{\circ} \mathrm{C}$. It must be noted that the NEBULA Technology is being used commercially since 2001. Unsupported Ni-W-Mo catalysts were shown recently to be more active than a traditional supported reference catalyst for HDS of a straight-run gas oil ${ }^{53}$. However, comparison with our results is not straightforward, as these catalysts were diluted with an alumina binder, and catalytic tests were performed at a considerably lower space velocity (LHSV $=2 \mathrm{~h}^{-1}$, instead of 39$150 \mathrm{~h}^{-1}$ used in this work).

Secondly, combining results of experiments done at a LHSV of $39 \mathrm{~h}^{-1}$ and at a LHSV of $150 \mathrm{~h}^{-1}$, the trend of activity is the following: MT072 (62 at\%Ni) > MT043 (69 at\%Ni) and MT072 $(62$ at $\% \mathrm{Ni})>\mathrm{MT0} 22(54 \mathrm{at} \% \mathrm{Ni})$. This suggests that an optimum atomic percentage of $\mathrm{Ni}$ exits (around $60 \mathrm{at} \% \mathrm{Ni}$ ) for which the conversion of 4,6-DMDBT is maximum. We think that the higher the $\mathrm{Ni}$ content in the material, the higher the $\beta-\mathrm{NiMoO}_{4}$ proportion phase in our unsupported HDS catalyst precursor. As known, when sulfided, the $\beta-\mathrm{NiMoO}_{4}$ is the most active phase in HDS. Moreover, it is known that the active sites are located on the $\mathrm{MoS}_{2}$ layers whereas Ni has a promoting effect. An excess of $\mathrm{Ni}$ will cover the $\mathrm{MoS}_{2}$ surface and may reduce the accessibility of sulfur compounds to the active sites. Thus, there should be a maximum Ni content (comprised between 54 at\% and 69 at\% of $\mathrm{Ni}$ ) for which the formation of the $\beta-\mathrm{NiMoO}_{4}$ phase is maximized without diminishing the number of active sites. An optimum $\mathrm{Ni} /(\mathrm{Mo}+\mathrm{Ni})$ mole ratio of 0.5 was also found for unsupported NiMo sulfide catalysts prepared by means of hydrothermal synthesis ${ }^{54}$. The sample with this composition gave maximum DBT and 4,6-DMDBT conversion at $350^{\circ} \mathrm{C}$ under batch conditions.

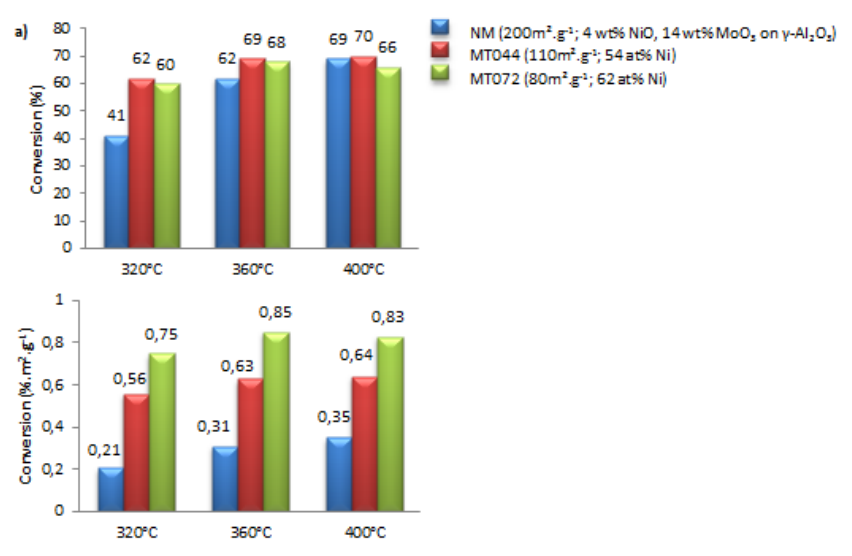



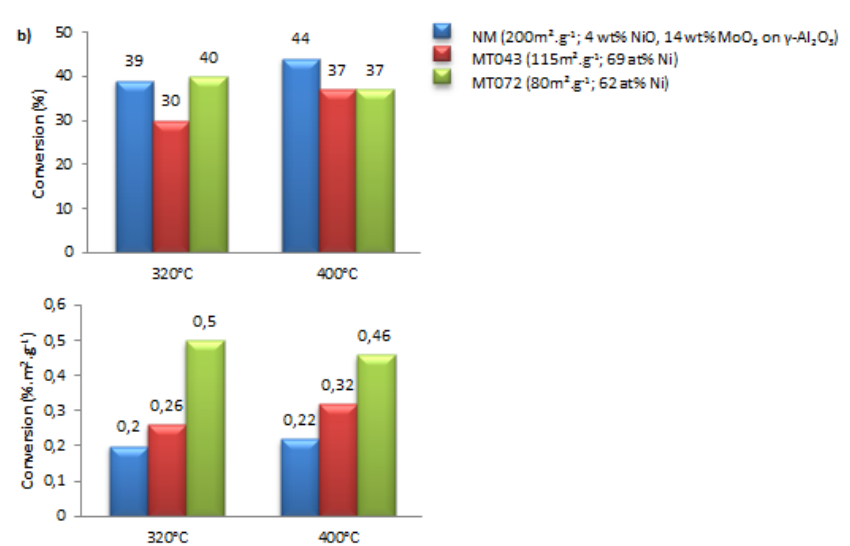

Figure 5: a) Conversion of 4,6-DMDBT in a model feedstock (see Experimental part, LHSV $=39 \mathrm{~h}^{-1}$ ), b) Conversion of 4,6 -DMDBT in a model feedstock (see Experimental part, LHSV $=150 \mathrm{~h}^{-1}$ )

Our samples have been tested under HDS conditions for deep-HDS of a complex model feedstock in order to study their efficiency of removing organosulfur molecules. They have shown significantly higher conversion as compared to a commercial reference at low temperatures $\left(320^{\circ} \mathrm{C}\right)$. This could be translated into reduced energetics or catalyst related costs when using the bulk precursors obtained by continuous supercritical synthesis at conversion levels comparable to those obtained with conventional supported catalysts. It has also been shown that a maximum of activity exists for a $\mathrm{Ni}$ content around 60 at\%.

Finally, tests were carried out on an industrial Light Cycled Oil (LCO) feedstock $(\mathrm{S}$ content $=5200 \mathrm{wppm}$, more details are given in S.I.) in order to evaluate the behaviour of our material under more realistic deep-HDS conditions. The preliminary results obtained at a pressure of 3.5 MPa, LHSV of $150 \mathrm{~h}^{-1}$ and MG/ML of 5, are presented in Figure 6. Even though experimental conditions were not fully optimized, this first set of experiments demonstrates the capability of the new materials described in this work for the desulfurization of an industrial feedstock and evidences their potential as deep-HDS bulk catalysts.

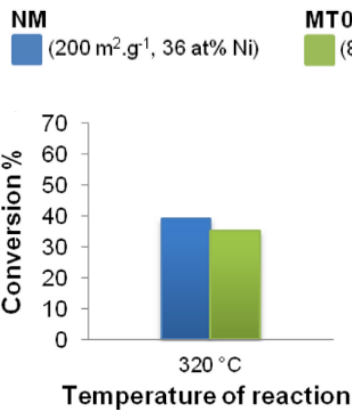

\section{2}

$\left(80 \mathrm{~m}^{2} \cdot \mathrm{g}^{-1}, 62\right.$ at $\%$ of $\left.\mathrm{Ni}\right)$

MPare 6: Total sulfur conversion by
$\mathrm{MPV}=150 \mathrm{~h}-1, \mathrm{MG} / \mathrm{ML}=5$ )

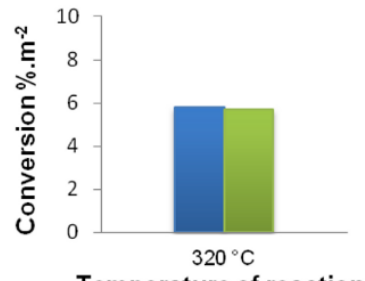

Temperature of reaction
This paper proposes a novel, fast and continuous method to produce high specific surface area deep HDS unsupported catalyst precursors with controlled composition using supercritical water/alcohols mixtures. Furthermore, this method provides an exceptional opportunity to produce nanostructured catalyst precursors in an environmentally friendly medium with high production rate and possible scale up at andustrial scale. This study describes the synthesis of high surface area materials $\mathrm{Ni}-\mathrm{Mo}$ and Co-Mo based oxides in supercritical fluids. The most active phases in $\mathrm{HDS}\left(\mathrm{NiMoO}_{4} .0 .75 \mathrm{H}_{2} \mathrm{O}\right.$ and $\left.\beta-\mathrm{NiMoO}_{4}\right)$, according to the literature, have been obtained and stabilized at room temperature. It has been shown that the nature of the alcohol plays a major role in the evolution of surface area.

Catalytic tests have shown better conversion of 4,6-DMDBT than the commercial reference and the deep-HDS reaction can be performed at lower temperature when using these nanostructured unsupported catalysts. It has also been demonstrated that there is an optimal value for $\mathrm{Ni}$ concentration where the activity of the catalyst is the maximum.

\section{Acknowledgements}

This work was supported by the CNRS and UPV. Dr M. Théodet is grateful to the French Ministry of Education, Research and Technology (MENRT) for a doctoral grant. The authors acknowledge Multifunctional Materials Institute (EMMI). Dr S. Pechev is also acknowledged for his priceless help in interpreting the XRD patterns.

Financial support by the Spanish Government-MINECO through “Severo Ochoa” (SEV 2012-0267), Consolider Ingenio 2010Multicat, CTQ2015-70126-R, and by the European Union through ERC-AdG-2014-671093 - SynCatMatch is acknowledged.

\section{Notes and references}

${ }^{a}$ CNRS, ICMCB, UPR 9048, F-33600 Pessac, France.

${ }^{\mathrm{b}}$ Univ. Bordeaux, ICMCB, UPR 9048, F-33600 Pessac, France

${ }^{c}$ Instituto de Tecnología Químíca (UPV-CSIC), Universidad Polítecnica de Valencia, Consejo Superior de Investigaciones Científícas, 46022 Valencia, Spain

Corresponding authors :

\# Dr C. Martinez, UPV-CSIC av. de los Naranjos s/n, 46022 Valencia, Spain. Email: cmsanche@upvnet.upv.es

* Dr C. Aymonier, ICMCB-CNRS, 87 avenue du Dr Albert Schweitzer, 33608 Pessac Cedex, France. Email: cyril.aymonier@icmcb.cnrs.fr Electronic Supplementary Information (ESI) available: See DOI: $10.1039 / \mathrm{b} 000000 \mathrm{x} /$

\section{Conclusions}

2. Ministry of Economy Trade and Industry (METI). Law on the

Quality Control of Gasoline and Other Fuels (Fuel Quality Control

The European Parliament \& The Council of the European Union. DIRECTIVE 2009/30/EC OF THE EUROPEAN PARLIAMENT AND OF THE COUNCIL of 23 April 2009. (2009). 
Law). (2014).

3. Environmental Protection Agency. Control of Air Pollution From New Motor Vehicles: Tier 2 Motor Vehicle Emissions Standards and Gasoline Sulfur Control Requirements. 65, (2000).

4. Environmental Protection Agency. Diesel Pump Labeling Requirements -Fact Sheet-. (2006).

5. Derbyshire, F. J. Catalysis in Coal Liquefaction: New Directions for Research. Volume 8. (IEA Coal Research, 1988). at 〈http://books.google.fr/books?id=q95pQgAACAAJ>

Donath, E. E. in Catal. Sci. Technol. (Anderson, J. R. \& Boudart, M.) 1-38 (Springer Berlin Heidelberg, 1982). doi:10.1007/978-3642-93223-6

7. Hoering, M. \& Donath, E. E. Early Coal Hydrogenation Catalysis. Fuel Process. Technol. 1, 3-20 (1977).

8. Digne, M., Marchand, K. \& Bourges, P. Monitoring Hydrotreating Catalysts Synthesis and Deactivation using Raman Spectrometry. Oil Gas Sci. Technol. - Rev. l'IFP 62, 91-99 (2007).

9. Topsøe, H., Clausen, B. S. \& Massoth, F. E. Hydrotreating Catalysis. (Springer Berlin Heidelberg, 1996). doi:10.1007/978-3642-61040-0

10. Oyama, S. T., Gott, T., Zhao, H. \& Lee, Y.-K. Transition metal phosphide hydroprocessing catalysts: A review. Catal. Today 143, 94-107 (2009).

11. Chianelli, R. R., Berhault, G. \& Torres, B. Unsupported transition metal sulfide catalysts: 100 years of science and application. Catal. Today 147, 275-286 (2009).

12. Eijsbouts, S., Mayo, S. W. \& Fujita, K. Unsupported transition metal sulfide catalysts: From fundamentals to industrial application. Appl. Catal. A Gen. 322, 58-66 (2007).

13. Hermann, N., Brorson, M. \& Topsøe, H. Activities of unsupported second transition series metal sulfides for hydrodesulfurization of sterically hindered 4,6 -dimethyldibenzothiophene and of unsubstituted dibenzothiophene. Catal. Letters 65, 169-174 (2000).

14. Ho, T. C. Hydrogenation of Aromatics over HydrodenitrogenationSelective and Hydrodesulfurization-Selective Catalysts. Ind. Eng. Chem. Res. 32, 1568-1572 (1993).

15. Ho, T. C., Jacobson, A. J., Chianelli, R. R. \& Lund, C. R. F. Hydrodenitrogenation-Selective Catalysts: I. Fe Promoted Mo/W Sulfides. J. Catal. 138, 351-363 (1992).

16. Ho, T. C. Deep HDS of diesel fuel: chemistry and catalysis. Catal. Today 98, 3-18 (2004).

17. Ho, T. C., Chianelli, R. R. \& Jacobson, A. J. Promotion effects in bulk metal sulfide catalysts. Appl. Catal. A Gen. 114, 127-139 (1994).

18. Yue, L. et al. Applied Catalysis A : General Size-dependent activity of unsupported Co-Mo sulfide catalysts for the hydrodesulfurization of dibenzothiophene. 512, 85-92 (2016).

19. Wang, R. \& Smith, K. J. Preparation of Unsupported NiMoP Catalysts for 4,6-Dimethyldibenzothiophene Hydrodesulfurization. Catal. Letters 144, 1594-1601 (2014).

20. Lewandowski, M., Szyma, A., Sayag, C. \& Beaunier, P. Applied Catalysis B : Environmental Atomic level characterization and sulfur resistance of unsupported W 2 C during dibenzothiophene hydrodesulfurization . Classical kinetic simulation of the reaction. 144, 750-759 (2014).

21. Bai, C., Beeckman, J., McCarthy, S., Hou, Z. \& Wu, J. Preaparation of bulk metallic group VIII/group VIB metal catalysts. 57 (2009).

22.

Soled, S. L., Miseo, S., Eijsbouts, S. \& Plantenga, F. L. Hydroprocessing using bulk bimetallic catalysts. (2007). at <http://www.google.com/patents/WO2007050632A2?cl=en>

23. Paraguay-Delgado, F., García-Alamilla, R., Lumbreras, J. A., Cizniega, E. \& Alonso-Núñez, G. Synthesis of Ni-Mo-W Sulfide Nanorods as Catalyst for Hydrodesulfurization of Dibenzothiophene. J. Nanosci. Nanotechnol. 8, 6406-64013 (2008).

24. Maione, A. \& Devillers, M. Solid solutions of Ni and Co molybdates in silica-dispersed and bulk catalysts prepared by solgel and citrate methods. J. Solid State Chem. 177, 2339-2349 (2004).

25. Vie, D. et al. Freeze-Dried Precursor-Based Synthesis of Nanostructured Cobalt-Nickel Molybdates Co 1 - x Ni x MoO 4. Chem. Mater. 16, 1697-1703 (2004).

26. Olivas, A., Galván, D. H., Alonso, G. \& Fuentes, S. Trimetallic NiMoW unsupported catalysts for HDS. Appl. Catal. A Gen. 352, 10-16 (2009).

27. Brito, J. L. \& Barbosa, A. L. Effect of Phase Composition of the Oxidic Precursor on the HDS Activity of the Sulfided Molybdates of Fe (II), Co (II), and Ni (II). J. Catal. 171, 467-475 (1997).

28. Brito, J. L., Barbosa, A. L., Albornoz, A., Severino, F. \& Laine, J. Nickel molybdate as precursor of HDS catalysts : effect of phase composition. Catal. Letters 26, 329-337 (1994).

29. Soled, S. L., Sabato, M., Eijsbouts, S. \& Plantenga, F. L. HYDROPROCESSING USING BULK BIMETALLIC CATALYSTS. 1, 11 (2007).

30. Huirache-Acuna, R. et al. Unsupported trimetallic CoMoW sulfide HDS catalysts prepared by in situ decomposition of sulfurcontaining precursors. Catal. Today 250, 28-37 (2015).

31. Li, Y. H. \& Zhu, Y. Q. Research Progress of Unsupported Nano Catalyst. Adv. Mater. Res. 550-553, 284-291 (2012).

32.

Bej, S. K., Maity, S. K. \& Turaga, U. T. Search for an efficient 4,6DMDBT Hydrodesulfurization catalyst : A Review of Recent Studies. Energy \& Fuels 18, 1227-1237 (2004).

33. Motos-Pérez, B., Uzio, D. \& Aymonier, C. Preparation of Nickel Phosphide Hydrodesulfurization Catalysts Assisted by Supercritical Carbon Dioxide. ChemCatChem 7, 3441-3444 (2015).

34. Slostowski, C., Marre, S., Babot, O., Toupance, T. \& Aymonier, C. Effect of Thermal Treatment on the Textural Properties of $\mathrm{CeO} 2$ Powders Synthesized in Near- and Supercritical Alcohols. ChemPhysChem 16, 3493-3499 (2015).

35. Cansell, F. \& Aymonier, C. Design of functional nanostructured materials using supercritical fluids. J. Supercrit. Fluids 47, 508516 (2009).

36. Philippot, G. et al. Coupling in situ synchrotron radiation with ex situ spectroscopy characterizations to study the formation of Ba1-xSrxTiO3 nanoparticles in supercritical fluids. J. Supercrit. Fluids 87, 111-117 (2014). 
37. Reverón, H. et al. Supercritical Fluid Route for Synthesizing Crystalline Barium Strontium Titanate Nanoparticles. J. Nanosci. Nanotechnol. 5, 1741-1744 (2005).

38. Reverón, H. et al. Single-step synthesis of well-crystallized and pure barium titanate nanoparticles in supercritical fluids. Nanotechnology 16, 1137-1143 (2005).

39. Philippot, G. et al. Continuous BaTi1-yZryO3 $(0 \leq \mathrm{y} \leq 1)$ nanocrystals synthesis in supercritical fluids for nanostructured lead-free ferroelectric ceramics. Mater. Des. 86, 354-360 (2015).

40. Adschiri, T., Lee, Y.-W., Goto, M. \& Takami, S. Green materials synthesis with supercritical water. Green Chem. 13, 1380-1390 (2011).

41. Smith, G. W. The crystal structures of cobalt molybdate CoMoO 4 and nickel molybdate NiMoO 4. Acta Crystallogr. 15, 1054-1057 (1962).

42. Abrahams, S. C. \& Reddy, J. M. Crystal Structure of the Transition-Metal Molybdates. I. Paramagnetic Alpha-MnMoO4. J. Chem. Phys. 43, 2533 (1965).

43. Rodriguez, J. A., Chaturvedi, S., Hanson, J. C., Albornoz, A. \& Brito, J. L. Electronic Properties and Phase Transformations in CoMoO 4 and NiMoO 4 : XANES and Time-Resolved Synchrotron XRD Studies. J. Phys. Chem. B 102, 1347-1355 (1998).

44. Rodriguez, J. A., Chaturvedi, S. \& Hanson, J. C. Reaction of H2 and $\mathrm{H} 2 \mathrm{~S}$ with $\mathrm{CoMoO} 4$ and NiMoO4: TPR, XANES, TimeResolved XRD, and Molecular-Orbital Studies. J. Phys. Chem. B 103, 770-781 (1999).

45. Ding, Y., Wan, Y., Min, Y.-L., Zhang, W. \& Yu, S.-H. General synthesis and phase control of metal molybdate hydrates MMoO4.nH2O ( $\mathrm{M}=\mathrm{Co}, \mathrm{Ni}, \mathrm{Mn}, \mathrm{n}=0,3 / 4,1)$ nano/microcrystals by a hydrothermal approach: magnetic, photocatalytic, and electrochemical properties. Inorg. Chem. 47, 7813-7823 (2008).

46. Eda, K., Kato, Y., Ohshiro, Y., Sugitani, T. \& Whittingham, M. S. Synthesis, crystal structure, and structural conversion of $\mathrm{Ni}$ molybdate hydrate NiMoO4.nH2O. J. Solid State Chem. 183, 1334-1339 (2010).

47. F., D. R. HOW THERMAL TREATMENT INFLUENCES THE PHASE TRANSITION OF NiMo04. Thermochim. Acta $\mathbf{8 5}, 139$ 142 (1985).

48. Klissurski, D., Mancheva, M., Iordanova, R., Tyuliev, G. \& Kunev, B. Mechanochemical synthesis of nanocrystalline nickel molybdates. J. Alloys Compd. 422, 53-57 (2006).

49. Slostowski, C., Marre, S., Babot, O., Toupance, T. \& Aymonier, C. Near- and Supercritical Alcohols as Solvents and Surface Modifiers for the Continuous Synthesis of Cerium Oxide Nanoparticles. Langmuir 28, 16656-16663 (2012).

50. Di Renzo, F., Mazzocchia, C., Thomas, G. \& Vernay, A. M. FORMATION AND PROPERTIES OF THE SOLID SOLUTION OF NiO IN NiMoO4. React. Solids 6, 145-155 (1988).

51. Mazzocchia, C., Di Renzo, F., Aboumrad, C. \& Thomas, G. Stability of alpha-nickel molybdate. Solid Stale lonics 32/33, 228 233 (1989).

52. Ponceblanc, H., Millet, J.-M., Coudurier, G., Legendre, O. \& Védrine, J. C. Solid-Solid Phase Equilibria In the Binary System CoMo04-FeMo04 and Effect of Fe(III) on the Phase Equilibria. $J$. Phys. Chem. 96, 9462-9465 (1992).
53. Zhang, L., Long, X., Li, D. \& Gao, X. Study on high-performance unsupported Ni-Mo-W hydrotreating catalyst. Catal. Commun. 12, 927-931 (2011).

54. Yoosuk, B., Song, C., Kim, J. H., Ngamcharussrivichai, C. \& Prasassarakich, P. Effects of preparation conditions in hydrothermal synthesis of highly active unsupported NiMo sulfide catalysts for simultaneous hydrodesulfurization of dibenzothiophene and 4,6-dimethyldibenzothiophene. Catal. Today 149, 52-61 (2010). 
Continuous supercritical synthesis of unsupported and high specific surface area catalyst precursors for deep-hydrodesulfurization

M. Théodet ${ }^{a, b, c}$, C. Quilfen
C. Aymonier
C,b

\section{Supporting information:}

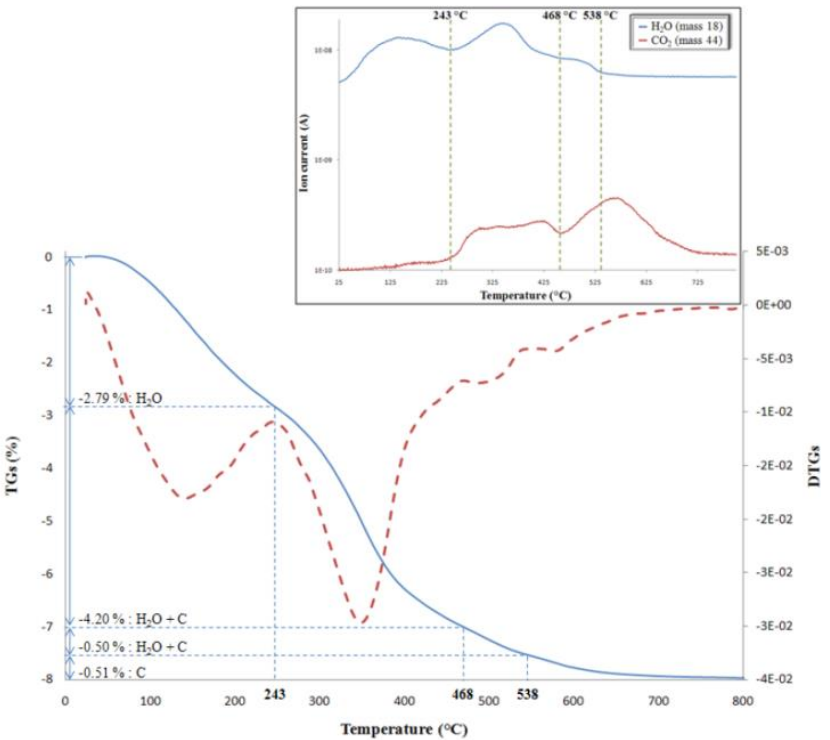

Figure S1: TGA-MS of the stoichiometric Ni-Mo based powder synthesized in supercritical $\mathrm{H}_{2} \mathrm{O} / \mathrm{EtOH}$ mixture, from room temperature to $800^{\circ} \mathrm{C}$ under $\mathrm{Ar}$ atmosphere, ramp rate $1^{\circ}$ C.min ${ }^{-1}$

Table S1: Cell parameters obtained for the stoichiometric NiMo based powder synthesized in supercritical $\mathrm{H} 2 \mathrm{O} / \mathrm{EtOH}$ mixture annealed at $400^{\circ} \mathrm{C}$.

\begin{tabular}{|c|c|c|c|c|}
\hline Space group & $\mathrm{a}(\AA)$ & $\mathrm{b}(\AA)$ & $\mathrm{c}(\AA)$ & $\beta(\AA)$ \\
\hline $\mathrm{C} 2 / \mathrm{m}$ & $10.187(5)$ & $9.246(5)$ & $7.020(2)$ & $107.09(3)$ \\
\hline JCPDS 45-0142 & 10,184 & 9.241 & 7.0189 & 107.09 \\
\hline
\end{tabular}

Table S2: Cell parameters obtained at $200^{\circ} \mathrm{C}$ for the stoichiometric NiMo based powder synthesized in supercritical $\mathrm{H} 2 \mathrm{O} / \mathrm{EtOH}$, when cooling down after investigation in temperature.

\begin{tabular}{|c|c|c|c|c|}
\hline Space group & $\mathrm{a}(\AA)$ & $\mathrm{b}(\AA)$ & $\mathrm{c}(\AA)$ & $\beta(\AA)$ \\
\hline $\mathrm{C} 2 / \mathrm{m}$ & $9.589(6)$ & $8.760(6)$ & $7.654(5)$ & $114.16(4)$ \\
\hline JCPDS 86-0361 & 9.566 & 8.734 & 7.649 & 114.22 \\
\hline
\end{tabular}

Table S3: Detailed composition of the model feedstock.

\begin{tabular}{lcc}
\hline Compound & Boiling point $\left({ }^{\circ} \mathrm{C}\right)$ & Concentration \\
\hline Heptane & 99 & $30 \mathrm{wt} \%$ \\
Dodecane & 216 & $30 \mathrm{wt} \%$ \\
Hexene & 63 & $15 \mathrm{wt} \%$ \\
Octene & 123 & $15 \mathrm{wt} \%$ \\
Naphthalene & 218 & $5 \mathrm{wt} \%$
\end{tabular}

Benzene

80

$3 \mathrm{wt} \%$

Toluene

Thiophene

110

$2 \mathrm{wt} \%$

Methylthiophene

Tetrahydrothiophene

100 wppm (S)

Benzothiophene

113

119

100 wppm (S)

50 wppm (S)

50 wppm (S)

Dibenzothiophene

222

4,6-Dimethyldibenzothiophene

100 wppm (S) 100 wppm (S)

Table S4: D86 correlation corresponding to the industrial LCO

\begin{tabular}{cc}
\hline$\%$ Off & Temperature $\left({ }^{\circ} \mathrm{C}\right)$ \\
\hline IBP & 187 \\
10 & 239 \\
20 & 252 \\
30 & 263 \\
50 & 286 \\
70 & 318 \\
80 & 336 \\
90 & 359 \\
FBP & 390 \\
\hline
\end{tabular}

